\section{Identification of Preharvest Desiccants for Use in Onion Production}

\author{
Jorge E. Arboleya ${ }^{1}$, Joseph G. Masabni², Michael G. Particka ${ }^{3}$, \\ and Bernard H. Zandstra ${ }^{4}$
}

ADDITIONAL INDEX WORDs. bromoxynil, carfentrazone, copper sulfate, diquat, endothall, paraquat, pelargonic acid

\begin{abstract}
Summary. Dry bulb onion (Allium cepa) leaves may not dry down normally and bulbs may not attain dormancy during adverse growing seasons. An effective method of artificial leaf desiccation is needed to complement mechanical harvesting and onion conditioning for storage. Desiccants were tested in 1993, 1994, $1995,2001,2002,2003$ on onion leaves prior to harvest, and bulb quality was evaluated after 5 months or more of storage. Carfentrazone, diquat, and paraquat desiccated onion foliage well but increased bulb rot and reduced the percentage of marketable bulbs after storage. Bromoxynil and endothall desiccated onion foliage significantly without inducing rot or reducing the percentage of marketable bulbs. Copper sulfate and pelargonic acid increased desiccation of onion foliage but were not sufficiently effective for field use. Neither reduced the percentage of marketable bulbs. If bromoxynil or endothall were labelled for onion desiccation, they could be applied 10-14 days before harvest to enhance natural leaf senescence and facilitate mechanical harvest.
\end{abstract}

$\mathrm{O}$ nions produce new leaves from the center of the compressed stem until near maturity, after which new leaf bases continue to form leafless swollen bulb scales. As the bulb matures, the outermost leaf sheaths become dry and thin, forming protective scales. The remaining green leaves soften at the neck and become less turgid, which causes them to fall over (Brewster, 1994). This is referred to as the tops down stage of the onion growth cycle. The bulbs continue to gain size and weight as the photosynthetic reserves that have been held in the leaf tissues are translocated to the leaf bases (Tiessen et al., 1981; Voss, 1979). Onion bulb yield increases $10 \%$ to $40 \%$ after the initial lodging of the leaves (Brewster, 1990; Wall and Corgan, 1994). At full maturity, all leaves are brown and desiccated, and the bulb is dormant. As onions mature, natural growth inhibitors that maintain subsequent dormancy are translocated from the leaves to the bulbs. If the

Department of Horticulture, Michigan State University, East Lansing, MI 48824-1325.

This research was supported by the Michigan Agricultural Experiment Station and the Michigan Onion Research Committee.

${ }^{1}$ Former Research Assistant; current address: INIA, Las Brujas, Uruguay.

${ }^{2}$ Assistant Professor, Department of Horticulture, University of Kentucky, Princeton, KY 42445.

${ }^{3}$ Research Assistant

${ }^{4}$ Professor. onions are harvested before they are mature, less of the natural sprouting inhibitor is translocated to the growing point of the bulbs, and the bulbs may sprout during or after storage (Brewster, 1990).

In some years onions do not reach maturity and leaves remain green beyond the normal harvest period. If there are too many green leaves at the end of the growing season, it is difficult to harvest the bulbs mechanically, and the bulbs that have not reached dormancy may not store well. Late maturity may be the result of late planting, improper cultivar selection, inadequate heat during the growing season, or a damp, cool fall (Johnson, 1986; Pelter et al., 1992; Tiessen et al., 1981).

Onions that are not well dried and cured in the field are more susceptible to rot during and after storage. Therefore, it is necessary to dry the bulbs and shrink the necks as rapidly as possible after harvest to prevent pathogens from entering the bulbs (Kaufman and Lorbeer, 1967; Jones and Mann, 1968). Curing by forced air-drying will dry the outer scales and shrink the necks of the bulbs, but it has no effect on bulb dormancy (Hoffmann et al., 1996).

Onion growers have used several methods to hasten onion maturity in the field, including breaking the onion necks and flattening the leaves with a lightweight roller, undercutting the roots with a knife or rod weeder (Longbrake et al., 1974; Tiessen et al., 1981; Voss, 1979), and chemical desiccants (Harmer and Lucas, 1955).

Several bacterial soft rot diseases can infect onion bulbs, including sour skin (Burkholderia cepacia), slippery skin (Burkholderia gladioli pv. alliicola), soft rot (Erwinia carotovora), and center rot (Pantoea ananatis) (Schwartz and Krishna Mohan, 1995; Schwartz and Otto, 2000). In early stages of infection, the visual symptoms of these diseases are similar; infection begins at the neck of the bulb and travels down individual scales into the bulb. Infected bulbs remain firm and appear normal until the infection is well advanced, making it difficult to sort them out of a packing line. Bulbs infected by bacterial rots after preharvest chemical applications often remain firm through the storage period and the bacterial rot is evident only upon cutting bulbs in half. While the percentage of rotted bulbs may be small, their presence may cause the whole lot to exceed government market standards or consumer acceptance standards.

Several chemicals have been tested for onion desiccation by other researchers. Isenberg and Abel-Rahman (1972) applied neo-decanoic acid (NDA) to desiccate onion foliage to prepare for earlier machine harvest. Two weeks after NDA application, leaves of treated plants had $42 \%$ moisture and were ready for harvest while control plants had $85 \%$ moisture and were still green.

\begin{tabular}{llll}
\hline $\begin{array}{l}\text { Units } \\
\begin{array}{l}\text { To convert U.S. to SI, } \\
\text { multiply by }\end{array}\end{array}$ & U.S. unit & SI unit & $\begin{array}{l}\text { To convert SI to U.S., } \\
\text { multiply by }\end{array}$ \\
\hline 0.4047 & $\mathrm{acre}(\mathrm{s})$ & $\mathrm{ha}$ & 2.4711 \\
0.3048 & $\mathrm{ft}$ & $\mathrm{m}$ & 3.2808 \\
9.3540 & $\mathrm{gal} / \mathrm{acre}$ & $\mathrm{L} \cdot \mathrm{ha}^{-1}$ & 0.1069 \\
2.5400 & inch $(\mathrm{es})$ & $\mathrm{cm}$ & 0.3937 \\
0.4536 & $\mathrm{lb}$ & $\mathrm{kg}$ & 2.2046 \\
1.1209 & $\mathrm{lb} / \mathrm{acre}$ & $\mathrm{kg} \cdot \mathrm{ha}^{-1}$ & 0.8922 \\
1.6093 & $\mathrm{mph}$ & $\mathrm{km} \cdot \mathrm{h}^{-1}$ & 0.6214 \\
6.8948 & $\mathrm{psi}$ & $\mathrm{kPa}$ & 0.1450 \\
$\left({ }^{\circ} \mathrm{F}-32\right) \div 1.8$ & ${ }^{\circ} \mathrm{F}$ & ${ }^{\circ} \mathrm{C}$ & $\left(1.8 \times{ }^{\circ} \mathrm{C}\right)+32$
\end{tabular}


Table 1. Onion crop information for 6 years of onion desiccation experiments at Michigan State University Muck Research Farm, Laingsburg.

\begin{tabular}{|c|c|c|c|c|c|c|}
\hline & \multicolumn{6}{|c|}{ Experiment year } \\
\hline & 1993 & 1994 & 1995 & 2001 & 2002 & 2003 \\
\hline Cultivar & $\begin{array}{l}\text { Sweet } \\
\text { Sandwich }\end{array}$ & $\begin{array}{l}\text { Spartan } \\
\text { Banner } 80\end{array}$ & Comanche & Hustler & Cortland & Benchmark \\
\hline Planting date & 27 Apr. & 3 May & 10 May & 3 May & 30 Apr. & 17 May \\
\hline $\begin{array}{l}\text { Treatment date } \\
\qquad(\mathrm{DAP})^{\mathrm{z}}\end{array}$ & $\begin{array}{l}27 \text { Aug. } \\
(122)\end{array}$ & $\begin{array}{l}25 \text { Aug. } \\
(114)\end{array}$ & $\begin{array}{l}1 \text { Sept. } \\
(114)\end{array}$ & $\begin{array}{l}4 \text { Sept. } \\
(124)\end{array}$ & $\begin{array}{l}28 \text { Aug. } \\
(120)\end{array}$ & $\begin{array}{l}4 \text { Sept. } \\
(110)\end{array}$ \\
\hline Tops down & $50 \%$ to $60 \%$ & $25 \%$ to $30 \%$ & $70 \%$ to $80 \%$ & $70 \%$ to $80 \%$ & $70 \%$ to $80 \%$ & $40 \%$ to $75 \%$ \\
\hline Green leaves & $80 \%$ to $90 \%$ & $80 \%$ to $90 \%$ & $60 \%$ to $70 \%$ & $60 \%$ to $70 \%$ & $60 \%$ to $70 \%$ & $40 \%$ to $60 \%$ \\
\hline $\begin{array}{l}\text { Harvest } \\
\qquad(\mathrm{DAP} / \mathrm{DAT})^{\mathrm{y}}\end{array}$ & $\begin{array}{l}14 \text { Sept.) } \\
(140 / 18)\end{array}$ & $\begin{array}{l}12 \text { Sept. } \\
(141 / 27)\end{array}$ & $\begin{array}{l}19 \text { Sept. } \\
(132 / 18)\end{array}$ & $\begin{array}{l}\text { l Oct. } \\
(151 / 27)\end{array}$ & $\begin{array}{l}9 \text { Sept. } \\
(132 / 12)\end{array}$ & $\begin{array}{l}29 \text { Sept. } \\
(135 / 25)\end{array}$ \\
\hline
\end{tabular}

${ }^{2} \mathrm{DAP}=$ days after planting.

DAT $=$ days after treatment.

In other research, paraquat desiccated onion leaves rapidly, but treated bulbs had a higher percentage of rot than the controls. (Bubl et al., 1979; Richardson et al., 1977; Zschau and Bottcher, 1968). Endothall applied at $4 \mathrm{lb} /$ acre resulted in $29 \%$ rot in storage, while $1 \mathrm{lb} /$ acre was similar to the control (Richardson et al., 1977).

The only preharvest treatment currently available to onion growers is the sprout inhibitor maleic hydrazide (MH). $\mathrm{MH}$ is applied when $50 \%$ to $60 \%$ of the tops are down and still green (Hoffmann et al., 1996; Tiessen et al., 1981). MH helps keep mature onion bulbs in a dormant (nonsprouting) state in storage for a longer period of time, but it does not hasten maturity in the field or improve the quality or storability of bulbs.

Several chemicals that have been used commercially to desiccate onion leaves before harvest are no longer available, including xanthogen disulfide, diethyl dithiobis thionoformate, and dinoseb (Harmer and Lucas, 1955; Masiunas, 1991; Meister et al., 1983). An effective desiccant for onions should dry the leaves rapidly to avoid conditions favorable for development of disease pathogens. The chemical should induce dormancy of the growing point, and then dissipate rapidly, leaving no chemical residue in the bulbs. The purpose of this research was to identify suitable compounds that would desiccate onion leaves while not causing bulb rots in storage.

\section{Materials and methods}

The experiments were conducted at the Michigan State University Muck Soil Research Station, Laingsburg, on a Houghton Muck soil, Euic mesic typic Medisaprist, $80 \%$ organic matter, with a $\mathrm{pH}$ of 6.6 . The plots were 5.3 $\mathrm{ft}$ wide and $50 \mathrm{ft}$ long on raised beds with three rows 16 inches apart per bed. The experiments were designed as randomized complete blocks with three replications. Seeds were planted at a spacing of approximately 1 inch, to achieve a final stand of approximately 10 plants per $1 \mathrm{ft}$ of row, and a population of 237,000 plants/acre. The experiments were conducted in 1993, 1994, 1995, 2001, 2002, and 2003. Crop information for each year is listed in Table 1. Different cultivars were used each year to reflect common grower practices. The plots were maintained throughout the growing seasons with normal production practices and pesticides (Zandstra et al., 1996). Desiccants were applied when 25\% to $80 \%$ of the onion tops were down and the leaves were $40 \%$ to $90 \%$ green.
Desiccants were applied using a carbon dioxide backpack sprayer operated at a pressure of $30 \mathrm{psi}$, delivering a spray volume of $20 \mathrm{gal} /$ acre through four, 8002 flat fan nozzles at a walking speed of $3.2 \mathrm{mph}$.

Desiccation treatments and adjuvants are listed in Table 2. Foliar desiccation was rated 8 to $15 \mathrm{~d}$ after treatment, on a scale of $1 \%$ to $100 \%$, where $1=$ no desiccation and $100=$ complete desiccation of all leaves. All of the bulbs in each plot were harvested by hand and the tops removed with a roller topper. A total of 200 good quality medium and large (2 inches and larger) bulbs were placed in two 1-bushel (50 lb) boxes, cured for 2 weeks in ambient outdoor air (following normal grower practice) and then placed in common storage. Storage temperature decreased as ambient temperatures decreased, and then was maintained at $32^{\circ} \mathrm{F}$, which is common

Table 2. Chemical desiccation treatments for onion foliage in 1993-2003 at Laingsburg, Mich. Rates are pounds acid equivalent (a.e.) or active ingredient per acre.

\begin{tabular}{|c|c|c|c|c|c|c|}
\hline \multirow[b]{2}{*}{ Desiccant } & \multicolumn{6}{|c|}{ Experiment year } \\
\hline & 1993 & 1994 & 1995 & 2001 & 2002 & 2003 \\
\hline & & & & & & \\
\hline Bromoxynil & 0.5 & $1,1^{y}$ & $1^{y}$ & & $0.5^{y}$ & $0.5,0.5^{y} 0.5^{y}$ \\
\hline Carfentrazone & & & & $0.2^{y}$ & $0.1^{y} 0.2^{y}$ & \\
\hline Copper sulfate & & 5,10 & $10,10^{y}$ & & & \\
\hline Diquat & 0.25 & & & $0.5^{y}$ & $0.5^{y}$ & 0.5 \\
\hline Endothall & 1 & $1,1^{y}$ & $1,1^{y}$ & $1^{w}$ & $1^{y}$ & $1,1^{x}$ \\
\hline Paraquat & 0.5 & & $0.5^{y}$ & $0.5^{y}$ & $0.5^{y}$ & 0.5 \\
\hline $\begin{array}{l}\text { Pelargonic acid } \\
\text { Untreated control }\end{array}$ & & $8.4,16.8$ & 16.8 & & & \\
\hline
\end{tabular}

${ }^{2} \mathrm{l} \mathrm{lb} /$ acre $=1.1209 \mathrm{~kg} \cdot \mathrm{ha}^{-1}$.

yPlus organo-silicone surfactant $0.5 \% \mathrm{v} / \mathrm{v}$ (Silwet L-77; Loveland Industries, Greeley, Colo.).

xPlus urea ammonium nitrate $(28 \%) 1 \% \mathrm{v} / \mathrm{v}$.

"Plus liquid ammonium sulfate $(38 \%) 2.5 \% \mathrm{v} / \mathrm{v}$ (Bronc; Wilbur-Ellis Co., Union Gap, Wash.). 
grower practice, until the end of the experiments. The bulbs were taken out of storage and evaluated after at least 22 weeks of storage. Each bulb was observed for sprouts and any obvious external rots, and squeezed by hand to determine firmness. Sprouted, rotted, or soft bulbs were considered unmarketable. Then 50 bulbs ( 100 bulbs in 2003 ) from each plot that appeared to be solid and marketable were cut in half and examined for internal rot. Bulbs with any internal discoloration or rot were considered to be unmarketable.

All data was analyzed with analysis of variance, using the GLM procedure of SAS (SAS Institute, 2001). The data from each year were analyzed separately, and means were separated by least significant differences.

\section{Results and discussion}

A summary of the results from the 6 years of experiments is contained in Table 3. Bromoxynil desiccated onion leaves well every year that it was used, with an average desiccation of $79 \%$ in eight treatments in 5 years. Bromoxynil did not reduce onion bulb quality. Onions desiccated with bromoxynil averaged $89 \%$ marketable after storage, which was not different from the untreated control average of $92 \%$ marketable. The addition of organosilicone surfactant in 1994 and 2003 tended to increase desiccation, but the differences were nonsignificant. The addition of urea ammonium nitrate (UAN) in 2003 did not affect desiccation. Bromoxynil applied at $0.5 \mathrm{lb} /$ acre in 1993, 2002, and 2003 desiccated onion foliage similarly to diquat and paraquat. In 1994 and 1995 it was applied at $1 \mathrm{lb} / \mathrm{acre}$, with similar results. In years with excess green foliage or adverse weather conditions, the 1$\mathrm{lb} /$ acre rate of bromoxynil may insure more consistent desiccation.

Onion desiccation with carfentrazone was equal to or greater than all other treatments in 2001 and 2002, but carfentrazone increased bulb rot during storage both years. Carfentrazone decreased marketable bulbs by an average of $39 \%$ in 2001 and 2002 . The 0.1 and $0.2 \mathrm{lb} /$ acre rates were equally effective in desiccating onion leaves. Carfentrazone is too toxic to onion bulbs to be used for preharvest desiccation.
Copper sulfate did not increase desiccation of onion foliage in 1994, but significantly increased desiccation of foliage to $63 \%$ in 1995 , compared to the untreated control average of $43 \%$ desiccation. The addition of an organo-silicone surfactant did not improve desiccation with copper sulfate. The lack of consistent desiccation with copper sulfate makes it unlikely to be acceptable as an onion harvest aid.

Diquat desiccated onion leaves in 3 of 4 years tested, but also reduced bulb quality significantly each year that it was applied. Desiccation of foliage with diquat averaged $84 \%$ over 4 years. The diquat treatments averaged $30 \%$ unmarketable bulbs over 4 years, compared to the untreated control average of $6 \%$ unmarketable for the same years.

Endothall at $1 \mathrm{lb} /$ acre significantly increased desiccation in eight of nine treatments in 6 years, with an average desiccation of $78 \%$, compared to the untreated control average of $51 \%$ desiccation. Desiccation with endothall was statistically similar to that with paraquat and diquat in all years except 1993, when endothall was less effective.

Table 3. Foliar desiccation (desicc.) of onions in the field and percentage of marketable (mkt.) bulbs after 5 months or more of storage following foliar treatment with desiccants in 1993-2003.

\begin{tabular}{|c|c|c|c|c|c|c|c|c|c|c|c|c|}
\hline \multirow[b]{2}{*}{$\begin{array}{l}\text { Treatment } \\
(\text { (lb/acre a.e. or a.i. })^{\mathrm{z}}\end{array}$} & \multicolumn{2}{|c|}{1993} & \multicolumn{2}{|c|}{1994} & \multicolumn{2}{|c|}{1995} & \multicolumn{2}{|c|}{2001} & \multicolumn{2}{|c|}{2002} & \multicolumn{2}{|c|}{2003} \\
\hline & $\begin{array}{l}\text { Foliar } \\
\text { desicc. }\end{array}$ & $\begin{array}{l}\text { Mkt. } \\
\text { bulbs }\end{array}$ & $\begin{array}{l}\text { Foliar } \\
\text { desicc. }\end{array}$ & $\begin{array}{l}\text { Mkt. } \\
\text { bulbs }\end{array}$ & $\begin{array}{l}\text { Foliar } \\
\text { desicc. }\end{array}$ & $\begin{array}{l}\text { Mkt. } \\
\text { bulbs }\end{array}$ & $\begin{array}{l}\text { Foliar } \\
\text { desicc. }\end{array}$ & $\begin{array}{l}\text { Mkt. } \\
\text { bulbs }\end{array}$ & $\begin{array}{l}\text { Foliar } \\
\text { desicc. }\end{array}$ & $\begin{array}{l}\text { Mkt. } \\
\text { bulbs }\end{array}$ & $\begin{array}{l}\text { Foliar } \\
\text { desicc. }\end{array}$ & $\begin{array}{l}\text { Mkt. } \\
\text { bulbs }\end{array}$ \\
\hline Bromoxynil 0.5 & $87^{*}$ & 95 & & & & & & & & $77^{*}$ & 93 & \\
\hline Bromoxynil 0.5 + OSS & & & & & & & & & $97^{*}$ & 99 & $83^{*}$ & 87 \\
\hline Bromoxynil $0.5+$ UAN $^{x}$ & & & & & & & & & & & 70 & 88 \\
\hline Bromoxynil 1.0 & & & $67^{*}$ & 88 & & & & & & & & \\
\hline Bromoxynil $1.0+$ OSS & & & $70^{*}$ & 86 & $77^{*}$ & 87 & & & & & & \\
\hline Carfentrazone $0.1+$ OSS & & & & & & & & & $100^{*}$ & $74^{*}$ & & \\
\hline Carfentrazone $0.2+$ OSS & & & & & & & $77^{*}$ & $40^{*}$ & $100^{*}$ & $68^{*}$ & & \\
\hline Copper sulfate 5 & & & 33 & 87 & & & & & & & & \\
\hline Copper sulfate 10 & & & 37 & 88 & $63^{*}$ & 92 & & & & & & \\
\hline Copper sulfate $10+$ OSS & & & & & $63^{*}$ & 89 & & & & & & \\
\hline Diquat 0.5 & & & & & & & & & & & $83^{*}$ & $69^{*}$ \\
\hline Diquat $0.5+$ OSS & & & & & & & 60 & $55^{*}$ & $100^{*}$ & $76^{*}$ & & \\
\hline Endothall 1.0 & 83 & 95 & $67^{*}$ & 82 & $63^{*}$ & 89 & & & & & $97^{*}$ & 92 \\
\hline Endothall $1.0+\mathrm{AMS}^{\mathrm{w}}$ & & & & & & & $70^{*}$ & 94 & & & & \\
\hline Endothall $1.0+$ OSS & & & $60^{*}$ & 83 & $67^{*}$ & 87 & & & $100^{*}$ & 98 & & \\
\hline Endothall $1.0+$ UAN & & & & & & & & & & & $93^{*}$ & 85 \\
\hline Paraquat 0.5 & $90^{*}$ & $67^{*}$ & & & & & & & & & $83^{*}$ & 84 \\
\hline Paraquat $0.5+$ OSS & & & & & $97^{*}$ & $72^{*}$ & $73^{*}$ & $79^{*}$ & $100^{*}$ & 92 & & \\
\hline Pelargonic acid & 8.4 & 43 & 83 & & & & & & & & & \\
\hline Pelargonic acid & 16.8 & $60^{*}$ & 90 & $63^{*}$ & 91 & & & & & & & \\
\hline Untreated & 60 & 93 & 30 & 88 & 43 & 91 & 43 & 96 & 67 & 99 & 60 & 89 \\
\hline
\end{tabular}

*Significantly different from untreated within a column at $P=0.05$.

${ }^{\mathrm{z}} \mathrm{l} \mathrm{lb} /$ acre $=1.1209 \mathrm{~kg} \cdot \mathrm{ha}^{-1}$; a.e. $=$ acid equivalent.

'Organo-silicone surfactant.

xUrea ammonium nitrate.

wLiquid ammonium sulfate. 
The addition of adjuvants did not improve desiccation activity of endothall. Endothall did not reduce marketable bulbs in any year. Richardson et al. (1977) reported similar results with endothall on onions at $1 \mathrm{lb} /$ acre.

Paraquat desiccated onion leaves well (average of $89 \%$ ) in all years tested, but was somewhat toxic to onions. Paraquat treatments increased bulb rot in onions in 1993 and 1995, but not in 2001, 2002, or 2003. Paraquat treatments averaged $79 \%$ marketable bulbs over 5 years, compared to $94 \%$ marketable for the untreated controls. These results with diquat and paraquat are similar to results reported earlier by other researchers (Bubl et al., 1979; Masiunas, 1991; Richardson et al., 1977; Zschau and Bottcher, 1968).

Pelargonic acid at $16.4 \mathrm{lb} /$ acre (acid equivalent) desiccated an average of $61 \%$ of onion foliage in 1994 and 1995, compared to the untreated control average of $36 \%$, and did not reduce onion bulb quality. Pelargonic acid at $8.4 \mathrm{lb} /$ acre was ineffective for onion desiccation. Pelargonic acid is a foliar nonselective burn-down herbicide which acts by destroying membrane integrity (Vencill, 2002). It is only active on green, actively growing foliage, and thus it would be less effective on onion leaves that have begun to senesce. In both 1994 and 1995, the desiccants were applied when a large percentage of the onion foliage was still green, which probably contributed to its moderate effectiveness in those years. It probably is not sufficiently active for use as an onion desiccant.

Several other treatments were applied at least once during the series of experiments. Treatments that were ineffective in onion foliage desiccation were ammonium chloride $5 \mathrm{lb} / \mathrm{acre}$, flumioxazin 0.1 and $0.2 \mathrm{lb} / \mathrm{acre}$, imazamox $1 \mathrm{lb} /$ acre, potassium carbonate $2 \mathrm{lb} /$ acre, potassium hydroxide 2 $\mathrm{lb} /$ acre, sodium borate $10 \mathrm{lb} / \mathrm{acre}$, sodium molybdate $\mathrm{l} \mathrm{lb} /$ acre plus copper sulfate $4 \mathrm{lb} /$ acre, sulfentrazone 0.2 $\mathrm{lb} / \mathrm{acre}$, and urea ammonium nitrate 5 gal/acre. Glufosinate $0.44 \mathrm{lb} / \mathrm{acre}$ desiccated onion leaves well, but increased storage rots.

Michigan onion growers prefer to grow full-season onion cultivars because of the potential for greater yields and the longer storage life of the bulbs. But planting full-season cultivars increases the risk of immaturity and having excess green foliage and nondormant bulbs at harvest under adverse conditions. In normal years a desiccant is not needed for onion harvest, but in an adverse year it would help salvage the crop. Without an effective desiccant, onion growers must depend on undercutting, rolling and other cultural practices to facilitate onion maturity. However, cultural practices are never completely adequate to obtain the desired level of bulb maturity.

Bromoxynil and endothall are the most promising onion desiccants identified from this research. Both increased foliar desiccation of onions and did not reduce bulb quality. Bromoxynil is currently registered for early postemergence broadleaf weed control in onion. It may be possible to expand the label to include a late season application for desiccation if excess chemical residues do not remain in the bulbs. Endothall is not registered for onion, but it is labeled for preharvest desiccation of potato (Solanum tuberosum) vines, cotton (Gossypium hirsutum) foliage, and alfalfa (Medicago sativa) foliage for seed production. It may be possible to expand the label for use in onion.

\section{Literature cited}

Brewster, J.L. 1990. Physiology of crop growth and bulbing, p. 53-88. In: H.D. Rabinowitch and J.L. Brewster (eds.). Onions and allied crops. Vol. I, Botany, physiology, and genetics. CRC, Boca Raton, Fla.

Brewster, J.L. 1994. Onion and other vegetable alliums. CAB Intl., Wallingford, U.K.

Bubl, C., D. Richardson, and N. Mansour. 1979. Preharvest foliar desiccation and onion storage quality. J. Amer. Soc. Hort. Sci. 104(6):773-777.

Harmer, P. and R. Lucas. 1955. Muck soil management for onion production. Mich. State College Ext. Bul. 123, East Lansing.

Hoffmann, M.P., C.H. Petzoldt, and A.C. Frodsham. 1996. Integrated pest management for onions. Cornell Coop. Ext. Serv. New York State IPM Program Publ. 119.

Isenberg, M. and M. Abdel-Rahman. 1972. Effectiveness of a new onion top killer. HortScience 7(5):471-473.

Johnson, D.A. 1986. Botrytis neck rot of onion. Wash. State Univ. Ext. Bul.1359, Pullman.
Jones, H.A. and L.K. Mann. 1968. Onions and their allies. Interscience, New York.

Kaufman, J. and J.W. Lorbeer. 1967. Control of botrytis neck rot of onions by fungicidal dusts and desiccant chemicals. Plant Dis. Rptr. 51(8):696-699.

Longbrake, T., J. Larsen, S. Cotner, and R. Roberts. 1974. Keys to profitable onion production in Texas. Texas Agr. Ext. Bul. MP-971.

Masiunas, J. 1991. Chemical desiccation of onions for set production. HortScience 26(1):23-25.

Meister, R.T., G.L. Berg, C. Sine, S. Meister, and J. Poplyk. 1983. Farm chemicals handbook. Meister Publ., Willoughby, Ohio.

Pelter, G.Q., E.J. Sorensen, R.E. Thornton, and R. Stevens. 1992. Dry bulb onion production in the Columbia basin. Wash. State Univ. Ext. Bul. EB 1693, Pullman.

Richardson, D., C. Bubl, and N. Mansour. 1977. Evaluation of top desiccants on curing of Danvers yellow globe onions and subsequent storage quality. Acta Hort. 62:317-320.

SAS Institute Inc. 2001. SAS user's guide. SAS Inst., Cary, N.C.

Schwartz, H.F. and S. Krishna Mohan (eds.). 1995. Compendium of onion and garlic diseases. APS Press, St. Paul, Minn.

Schwartz, H.F. and K. Otto. 2000. First report of leaf blight and bulb decay of onion by Pantoea ananatis in Colorado. Plant Dis. 84(7):808.

Tiessen, H., L. Nonnecke, and M. Valk. 1981. Onions. Ministry of Agr. and Food. Ontario, Canada. Publ. 486.

Vencill, W.K. 2002. Herbicide handbook (8th ed.) Weed Sci. Soc. Amer., Lawrence, Kans.

Voss, R.E. 1979. Onion production in California. Univ. Calif. Ext. Publ. 4097, Davis.

Wall, M. and J. Corgan. 1994. Posharvest losses from delayed harvest and during common storage of short-day onions. HortScience 29(7):802-804.

Zandstra, B.H., E.J. Grafius, M.L. Lacy, and D.D. Warncke. 1996. Commercial vegetable recommendations: onions. Michigan State Univ. Ext. Bul. E-1307. East Lansing.

Zschau, K. and H. Bottcher. 1968. Experiments on the chemical killing of onion leaves. Albrecht-Thaer Archiv 12:951-962. (Abstr.). 